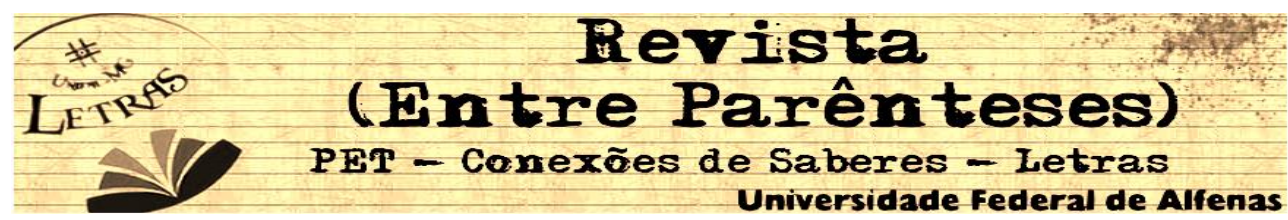

\title{
POR QUE ESTUDAR O DISCURSO HOMOSSEXUAL?
}

\author{
Daniel Mazzaro Vilar de Almeida \\ Universidade Federal de Alfenas (UNIFAL-MG) \\ Universidade Federal de Minas Gerais (UFMG) \\ letrasdaniel@yahoo.com.br
}

\begin{abstract}
Resumo: As atuais pesquisas na Sociologia, Antropologia e Psicologia (principalmente a Social) apontam o discurso como o berço do gênero, do sexo, da sexualidade e do corpo. A Teoria Queer desenvolvida, dentre outros, pela estadunidense Judith Butler, outorga grande importância à linguagem como gênese do sujeito, o que, inevitavelmente, redunda nas questões sociais. Dessa forma, faz-se necessário que a área da linguagem, mais especificamente a Análise do Discurso, faça suas contribuições para a elucidação do fenômeno sociodiscursivo indicado pela teoria supracitada. Assim, proponho, neste trabalho, apresentar alguns aportes da Semiolinguística, teoria desenvolvida por Patrick Charaudeau dentro do contexto da Análise do Discurso de Linha Francesa, que podem contribuir para o tratamento dos discursos de homossexuais masculinos e conjugá-los aos aportes da Teoria Queer de Butler.
\end{abstract}

Palavras-chave: Teoria Queer, Judith Butler, Teoria Semiolinguística, discurso homossexual

Resumen: Las investigaciones actuales en Sociología, Antropología y Psicología (principalmente la Social) apuntan el discurso como cuna del género, del sexo, de la sexualidad y del cuerpo. La Teoría Queer desarrollada, entre otros, por la estadunidense Judith Butler, otorga gran importancia al lenguaje como génesis del sujeto, lo que, inevitablemente, redunda en la cuestiones sociales. De esa forma, es necesario que el área del lenguaje, específicamente el Análisis del Discurso, haga sus contribuciones para la elucidación del fenómeno sociodiscursivo indicado por la teoría supra citada. Así, propongo, en este trabajo, presentar algunos aportes de la Semiolinguística, teoría desarrollada por Patrick Charaudeau dentro del contexto del Análisis del Discurso de Línea Francesa, que pueden contribuir para el tratamiento de los discursos de homosexuales masculinos y conjugarlos a los aportes de la Teoría Queer de Butler.

Palabras clave: Teoría Queer, Judith Butler, Teoría Semiolingüística, discurso homosexual

\section{Introdução}




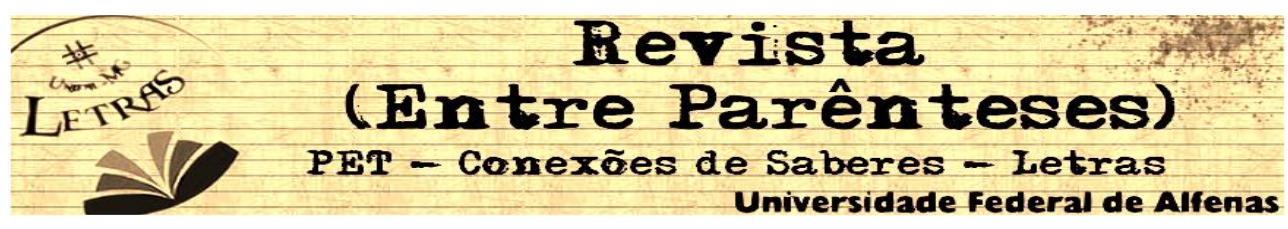

O tema da homossexualidade tem sido bastante discutido, provavelmente por possuir um histórico extremamente conturbado e por estar cada vez mais presente na sociedade. As perguntas sobre esse tema, que costumam girar em torno de dúvidas como "de onde surgiu o homossexual?", passaram a incluir outras mais políticas, como "por que não possuem todos os direitos que os heterossexuais?". As respostas, em ambos os casos, não são fáceis de serem dadas e, por isso, são diversas as áreas de estudos que se aproximam do tema para, de alguma forma, contribuir com um avanço.

O ser que hoje entendemos como homossexual possui uma história marcada por mudanças acentuadas, já que ora era visto como pecador, ora como enfermo, ora como delinquente, ora como transgressor, ora como promíscuo. Todo esse histórico levou a uma construção de uma imagem social turva do gay que pode se contradizer, ser incompleta, preconceituosa ou real.

Falar sobre quem é o homossexual/gay é muito complexo e, por vezes, contraditório. Falar sobre sua história é ainda mais complexo, dado que sua construção é relativamente recente e o que fazemos é lançar no passado o nosso entendimento atual.

Pode parecer estranho, mas o mundo nem sempre foi contra eles. Na verdade, nem sempre (e nem em todas as culturas) houve um questionamento sobre eles sob o ponto de vista sexual ${ }^{1}$. $\mathrm{Na}$ Antiguidade, por exemplo, as relações sexuais entre dois homens estavam ligadas a determinadas faixas etárias (na Grécia, era comum o homem viril, mais velho, deitar-se com um adolescente) ou

\footnotetext{
${ }^{1}$ Sugiro a leitura de "A Face e o Verso: Estudos sobre o homoerotismo II", de Jurandir Freire Costa (1995). Nesse livro, o autor faz importantes considerações sobre o sujeito como rede linguística de crenças e desejos mostrando como as categorizações e as nomenclaturas são, inevitavelmente, reflexos do hábito essencialista de pensar a fixidez do mundo. Eis, portanto, o que fazemos: classificamos, tendemos a deixar de fora as condições de variabilidade e olhamos para o passado com essa nova categoria criada. 


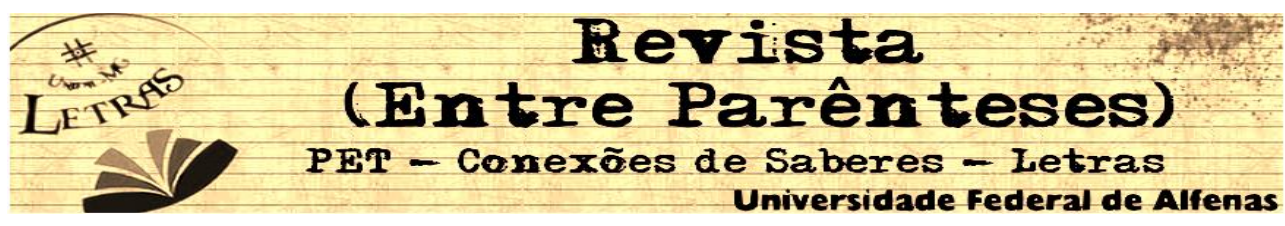

a determinadas circunstâncias (em Roma, deitava-se o senhor com seu escravo) que não excluíam, nesses mesmos indivíduos, práticas sexuais concorrentes com pessoas do sexo oposto.

De fato, acreditava-se que os homens que possuem uma alma esforçada, além de valor e caráter viris, buscam seus semelhantes, isto é, outros de valor e caráter viris. Assim, os gregos de forma geral consideravam o amor para com os garotos jovens perfeitamente compatível com uma identidade viril. Acreditava-se, inclusive, que os jovens, após os doze anos, só podiam absorver as virtudes de um bom cidadão se eles mantivessem relações sexuais com homens mais velhos. Daí o termo pederastia que, originalmente, designa a atração sexual primária entre homens adultos e adolescentes e pré-púberes. Por extensão de sentido, o termo é utilizado para designar qualquer relação homossexual masculina.

Historicamente, as relações sexuais entre pessoas do mesmo sexo tiveram diversas interpretações, desde certa aceitação social e educacional na Antiguidade até uma visão pecaminosa na Idade Média e de constituinte do quadro de doenças passíveis de exame, avaliação e tratamento no final do século XVIII.

Apenas no final do século XIX, começam as mudanças de perspectivas e o homossexual deixa de estar relacionado apenas à perversão que põe em conflito os direitos dos cidadãos nas novas sociedades burguesas europeias para cair nas graças dos estudos psíquicos. Sigmund Freud foi um dos mais conhecidos estudiosos da área, mas sua contribuição para o tema da homossexualidade é, no mínimo, questionável, já que, como analisa Costa (1995, p. 241), ele "não dispunha de critérios exclusivamente metapsicológicos, nem principalmente metapsicológicos, para definir quais as condições de possibilidade inconscientes da homossexualidade". Na verdade, ele partia "da linguagem ordinária e reencontrava-se, no fim do trajeto, o 


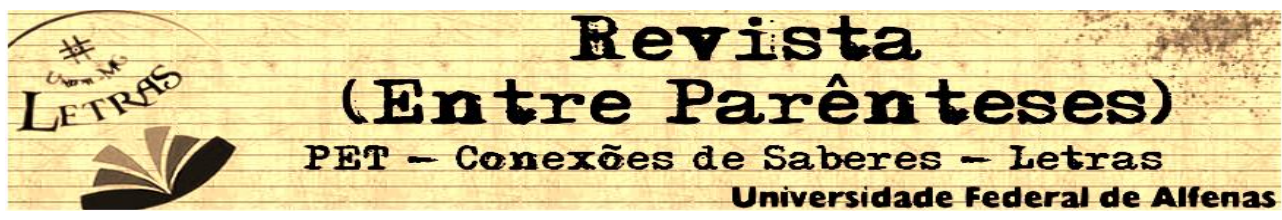

acordo naquela linguagem para definir o que era 'um homossexual' ou 'a homossexualidade'” (COSTA, 1995, p. 242). Quer dizer, Freud não estava consciente de sua dependência para com a linguagem ordinária, facilmente projetava o vocabulário sexual que havia herdado do século XIX em suas categorias clínicas e "admitia, tacitamente, a construção histórica dos referentes dos termos sexo e sexualidade, como constatações empíricas e científicas acima de quaisquer suspeitas" (COSTA, 1995, p. 243) ${ }^{2}$.

Mas, então, onde se encontra a questão da homossexualidade? O que os estudos linguísticos têm a ver com isso? Essas são as perguntas que nortearão este trabalho.

\section{Onde se encontra a questão da homossexualidade?}

Se, como vimos anteriormente, a homossexualidade não é necessariamente uma questão biológica, quer dizer, não possui uma gênese pautável na fisiologia, nem uma questão psicológica, onde mais procurar a sua "causa"?

A Teoria Queer, desenvolvida por vários estudiosos, parte do princípio de que a orientação sexual e a identidade sexual ou de gênero dos indivíduos são o resultado de um construto social e que, portanto, não existem papéis sexuais essencial ou biologicamente inscritos na natureza humana, mas sim formas socialmente variáveis de desempenhar um ou vários papéis sexuais.

${ }^{2}$ É importante, no entanto, deixar claro que o que Freud fazia não era, em hipótese alguma, uma teorização da homossexualidade, e sim uma análise e interpretação de casos seguidos de possíveis respostas, e nesse contexto, ele foi muito observador e singular para a época. O que acontece é que não há uma explicitação sobre termos que ele usa indiscriminadamente, como "mulher" e "homem" quando afirma, por exemplo, que o homossexual é uma mulher com pênis, ou um homem com alma de mulher. Parece que ora se refere ao corpo físico, ora à psique, e ora ao lugar comum social sobre o comportamento dessa divisão binária, o que pode gerar certa confusão.

4 Revista (Entre Parênteses) 


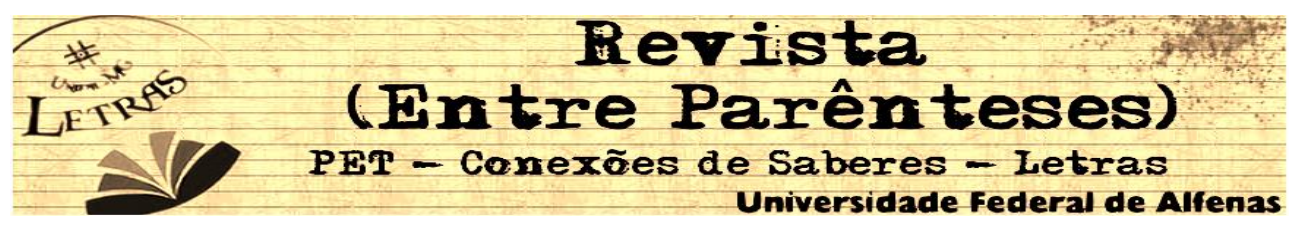

A origem do próprio termo que dá nome à teoria já remonta a essa ideia de construto social. Queer, em inglês, significa, literalmente, estranho, esquisito, excêntrico, e, usado para insultar, significa bicha. Atualmente, a palavra aparece no nome da teoria de forma reapropriada e, se olharmos as origens dos estudos queer, percebemos que suas raízes não são necessariamente o que hoje chamamos homossexuais e lésbicas, mas sim os estudos do feminismo.

Uma das maiores referências da atualidade no assunto é, provavelmente, a "teórica feminista, teórica queer e teórica gaylésbica"3 estadunidense Judith Butler, que possui um grande repertório do assunto em forma de livros, artigos e palestras. Sua obra Problemas de gênero: feminismo e subversão da identidade (em inglês, Gender problem), de 1990, é uma das mais conhecidas publicações da teoria feminista na qual se indaga sobre a construção dos gêneros e das identidades, uma vez que estão centradas em duas instâncias cruciais: o falocentrismo e a heterossexualidade compulsória.

Para a autora, tanto o gênero como a identidade são construções discursivas e são essas construções que the interessam ao pesquisar sobre o feminismo. Para Butler (2010, p. 206), "o sujeito culturalmente enredado negocia suas construções, mesmo quando estas constituem os próprios atributos de sua própria identidade". Com isso, o sujeito continua a encontrar seu ambiente discursivamente constituído numa estrutura epistemológica de oposição, pois, como lembra a autora, este cogito nunca é completamente do mundo cultural que esse sujeito negocia, seja

\footnotetext{
${ }^{3}$ É dessa forma, e nessa ordem, que Judith Butler se define em uma entrevista dada a Peter Osborne e Lynne Segal em Londre, em 1994, conforme registra Femenías (2003, p. 16).

$5 \frac{\text { Revista (Entre Parênteses) }}{$\cline { 2 - 2 }}
}




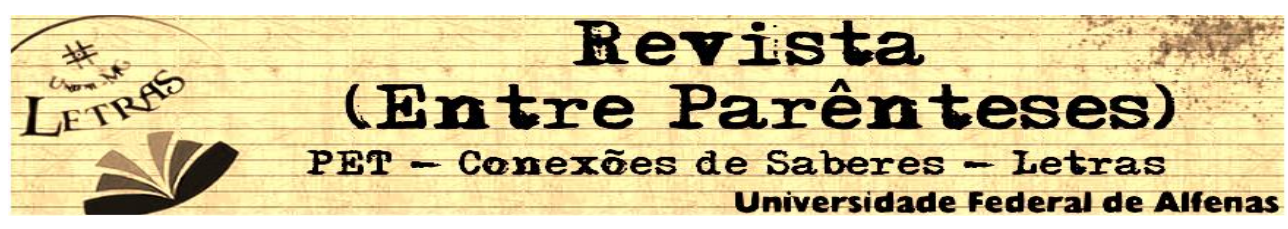

qual for a estreiteza da distância ontológica que o separa de seus atributos culturais.

Butler relaciona o gênero à identidade e afirma que, nesse caso, a linguagem não é um meio ou instrumento externo no qual se despeja um "eu" e onde se vislumbra um reflexo desse eu. Para ela, as condições que possibilitam a afirmação do "eu" são providas "pela estrutura de significação, pelas normas que regulam a invocação legítima ou ilegítima desse pronome, pelas práticas que estabelecem os termos de inteligibilidade pelos quais ele pode circular" (BUTLER, 2010, p. 207). Qualificar-se como uma identidade substantiva (o "eu" deixa de ser pronome e passa a ser substantivo) é, obviamente, uma tarefa muito difícil, pois há uma prática significante que busca ocultar seu próprio funcionamento e naturalizar seus efeitos.

O gênero enquanto identidade e, por consequência, seu questionamento, é, na obra de Butler, o mesmo que a análise das aparências que são geradas por regras e que se fiam na invocação sistemática e repetida de regras que condicionam e restringem as práticas culturalmente inteligíveis da identidade. Aliás,

compreender a identidade como uma prática, e uma prática significante, é compreender sujeitos culturalmente inteligíveis como efeitos resultantes de um discurso amarrado por regras, e que se insere nos atos disseminados e corriqueiros da vida linguística (BUTLER, 2010, p. 208 - grifo da autora).

Logo, o discurso se faz pelo e no sujeito e o sujeito se faz pelo e no discurso.

O gênero do ser humano, da mesma forma que outras facetas do sujeito, é consequência de certos discursos regidos por regras, os quais governam a invocação inteligível da identidade. Assim, o gênero (e, por extensão, o sujeito) não é determinado pelas 


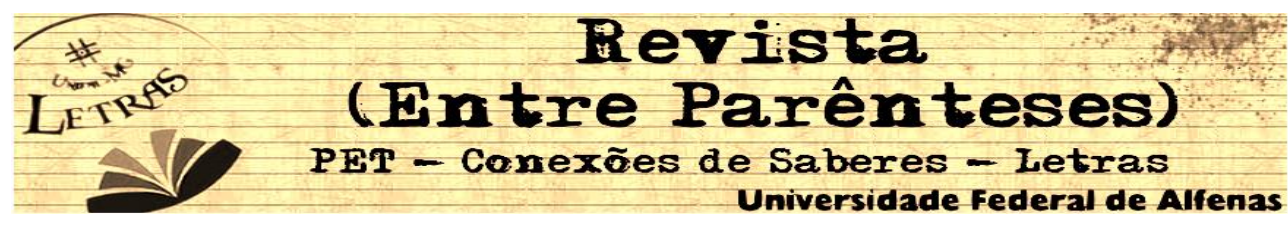

regras pelas quais é gerado, porque a significação não é um ato fundador, mas antes um processo regulado de repetição que tanto se oculta quanto impõe suas regras, precisamente por meio da produção de "efeitos substancializantes", nas palavras de Butler (2010, p. 209). De fato, ser um gênero é, sobretudo, estar comprometido com uma interpretação cultural no uso dos corpos, posicionado dinamicamente em um campo de possibilidades culturais. Dessa forma, não é possível "agregar" aos homens e mulheres certos valores e comportamentos sociais como biologicamente determinados, pois nada na natureza determina uma ordem certa social, e tampouco é possível referir-se significativamente aos comportamentos genéricos como "naturais" ou "antinaturais". Logo, o gênero é um aspecto fundamental da identidade que se adquire gradual e voluntariamente. "Ser mulher" ou "ser homem", por exemplo, implica um ato da vontade, uma construção que designa a variedade de modos nos quais se pode adquirir significado cultural ou reconhecer inteligibilidade ao processo de autoconstrução do gênero que "pode vir a ser".

Butler, como analisa Femenías (2003, p. 35), reforça que "para incorporarem-se ao mundo cultural, os indivíduos realizam um projeto ativo de gênero no qual atuam constantemente e que parece um fato natural". Assim, a natureza do corpo é apenas a superfície de uma invenção cultural. Mais que isso: a pesquisadora estadunidense assume em sua obra que sexo e gênero são intercambiáveis, pois ambos dão conta da "incardinação", da corporificação das marcas culturais. Como aponta Femenías (2003),

a demarcação das diferenças anatômicas não precede as interpretações culturais da diferença, e sim, pelo contrário, que a diferença já é em si mesma uma interpretação cultural que descansa sobre supostos normativos naturalizados. O 


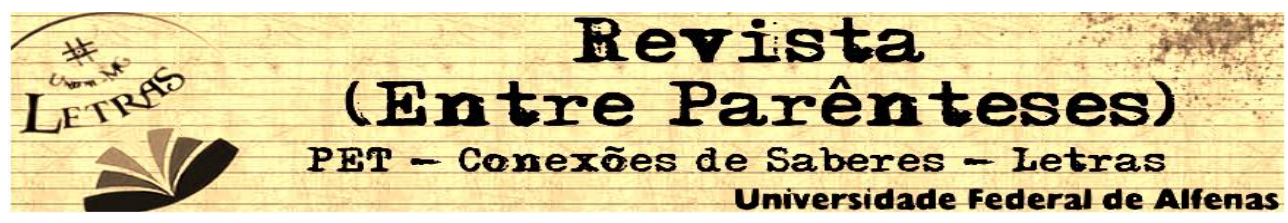

entrelaçamento do mundo cultural com o corpo é uma tarefa intensa que cada indivíduo realiza ativamente. Enquanto projeto que atua constantemente, parece, no entanto, um fato natural. (FEMENÍAS, 2003, p. 38)

Seguindo esse raciocínio, a existência do gênero significa que tacitamente se aceitam ou retrabalham as normas culturais que governam a interpretação do próprio corpo. E, se isso é assim, então o gênero também pode ser o lugar da subversão do sistema binário que o restringe. Como as oposições binárias perdem claridade e força enquanto termos descritivos, ao mesmo tempo perdem também utilidade funcional. Inclusive, como a ambiguidade de gênero pode adotar múltiplas formas, o gênero mesmo promete proliferar como fenômeno múltiplo para o qual se deverão encontrar novas palavras "classificatórias". Para Butler, o sistema de gêneros binários não é ontológica e necessariamente "dado", porque homem e mulher são formas já modeladas de existência corporal; na verdade, emergem como entidades substantivas desde uma perspectiva mitificada, subsidiária da metafísica da substância e, mais que isso, não há nada significativo no dimorfismo, exceto o interesse cultural de mantê-lo ${ }^{4}$.

Butler esclarece que boa parte das explicações habituais a respeito de homem/mulher ou masculino/feminino sugere certo determinismo dos mecanismos de significado inscritos em corpos anatomicamente diferenciados. Desse modo, os corpos acabam se considerando meros recipientes passivos de uma lei cultural

\footnotetext{
${ }^{4}$ Em vários pontos da obra de Jurandir Freire Costa (1995) o autor resgata textos que comprovam esse questionamento de Judith Butler. Um exemplo são os estudos do Estado burguês que transformaram a mulher em signo de guardiã da fragilidade da vida privada e justificaram a partir de sua biologia, marcada pela sua incapacidade "para desempenhos sociais na vida pública e como marca da vocação natural para os cuidados da casa" (COSTA, 1995, p. 113). Isso não passa, na verdade, de uma importante estratégia na nova ordem políticoeconômica burguesa.
} 


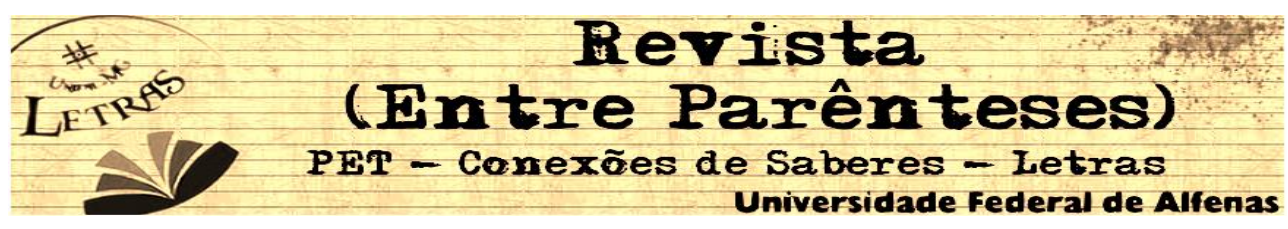

inexorável. Além disso, quando a cultura hegemônica constrói o gênero, parece fazê-lo em termos de um conjunto de leis que se parecem muito à formulação "a biologia é destino" resignificada em termos de "a cultura institui destino".

Como, no entanto, "incorporamos" as ideias de masculino/feminino, homem/mulher, heterossexual/homossexual? Butler acredita que a identidade é performativamente constituída, isto é, como na teoria dos atos de fala de Austin, a identidade (no caso, a identidade de gênero), quando é dita, não é meramente registrada como um estado de coisas, como uma informação, uma descrição, mas, na verdade, é uma ação, um "fazer". O gênero, dessa forma, é uma série de "atos", por assim dizer, que estão abertos a cisões, sujeitos a paródias de si mesmos, a autocríticas e àquelas exibições hiperbólicas do "natural" que, em seu exagero, revelam seu status fundamentalmente fantástico ${ }^{5}$. Em outras palavras, o gênero não é algo que somos, mas algo que fazemos, é uma sequência de atos. Mais que isso, o gênero é construído e constituído pela linguagem, o que significa que não há identidade de gênero que preceda a linguagem.

Salih (2012) propõe uma metáfora interessante para explicar esse pensamento. Segundo a leitora de Butler, "vestimos" um gênero, que é limitado pelas estruturas de poder no interior das quais está situado e, além disso, há possibilidades de proliferação e subversão que se abrem a partir dessas limitações. Dessa forma,

uma vez que estamos vivendo dentro da lei ou no interior de uma dada cultura, não há possibilidade de nossa escolha ser inteiramente "livre", e é bem provável que a "escolha" de nossas roupas

\footnotetext{
${ }^{5}$ Infelizmente, por questões de recorte, não vou me delongar na teoria de Butler. Sugiro, portanto, a leitura de Butler (2010) (uso uma tradução da obra de 1990), ou então a análise feita por Sara Salih em 2002 e possui tradução para o português, em 2012, pela editora Autêntica.
} 


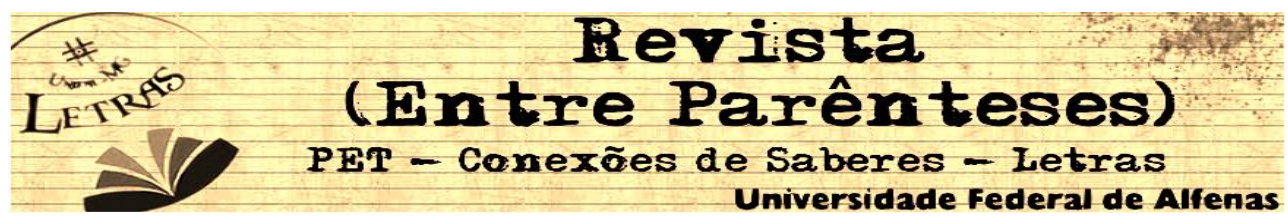

metafóricas se ajuste às expectativas ou talvez às demandas de nossos amigos ou colegas de trabalho, mesmo sem nos darmos conta de que estamos fazendo isso. Além disso, o conjunto de roupas disponíveis será determinado por fatores tais como a nossa cultura, o nosso trabalho, o nosso rendimento ou o nosso status e origem social. (SALIH, 2012, p. 72-73)

Segundo essa metáfora do armário, o gênero é performativamente constituído, do mesmo modo que a escolha de roupas de alguém é delimitada, talvez até predeterminada, pela sociedade, pela economia, pelo contexto no qual esse alguém está situado. Nossas escolhas não são livres, mas limitadas; existe certa restrição à escolha de gênero.

Mas o que tudo isso tem a ver com a Análise do Discurso? Vejamos as possíveis relações entre essa parte da Teoria Queer de Judith Butler e as contribuições da Análise do Discurso, principalmente a Semiolinguística desenvolvida por Patrick Charaudeau.

\section{O que os estudos linguísticos têm a ver com a homossexualidade?}

Como vimos anteriormente, Butler acredita que a generificação humana se faz via linguagem, mais especificamente por meio de enunciados performativos. No entanto, diferentemente do que propunha Austin em sua teoria, não há necessidade da presença de verbos performativos, como prometer, ordenar, permitir, declarar, perdoar etc., que marcavam a relação dizer-é-fazer. Pelo contrário, o ato performativo de gênero, na maioria das vezes, vem linguística e socialmente camuflado de ato constatativo e, dessa 


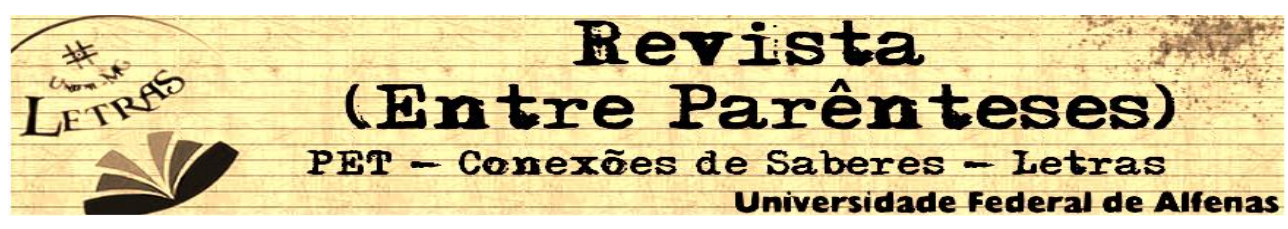

forma, ser homem, mulher, masculino, feminino, heterossexual ou homossexual (para não citar outras identidades) são tidos como naturais quando, na verdade, são construções discursivas.

A relação disso com a Análise do Discurso surge no fato de estarmos falando de um campo do saber no qual a linguagem é entendida como um fenômeno que deve ser estudado não apenas como formação linguística, mas também como formação histórica que se manifesta através de uma competência socioideológica. Além disso, a Análise do Discurso não é experimental, mas empíricodedutiva, e disso decorre o fato de partirmos, inevitavelmente, de um material empírico que é a linguagem e que está configurada na substância semiológica verbal e, às vezes, icônica.

Façamos um breve histórico. Nos anos de 1950, alguns estudiosos, como Harris, Jakobson e Benveniste, mostraram a possibilidade de ultrapassar as análises confinadas meramente à frase e estenderam os procedimentos a outros elementos que se chamariam enunciados. Dessa forma, Benveniste, por exemplo, dá relevo ao papel do sujeito falante no processo da enunciação e procura mostrar como acontece a inscrição desse sujeito nos enunciados que ele emite.

A partir desse pensamento, várias perspectivas teóricas aparecem no campo da linguagem. É o caso da Análise do Discurso de Linha Francesa (ADF), uma das mais imanentes, já que foi a primeira a articular a linguística com o marxismo e a psicanálise sendo, dessa forma, basicamente interdisciplinar. Para ela,

a linguagem passa a ser um fenômeno que deve ser estudado não só em relação ao seu sistema interno, enquanto formação linguística a exigir de seus usuários uma competência específica, mas também enquanto formação ideológica, que se manifesta através de uma competência socioideológica". (BRANDÃO, 2004, p. 17) 


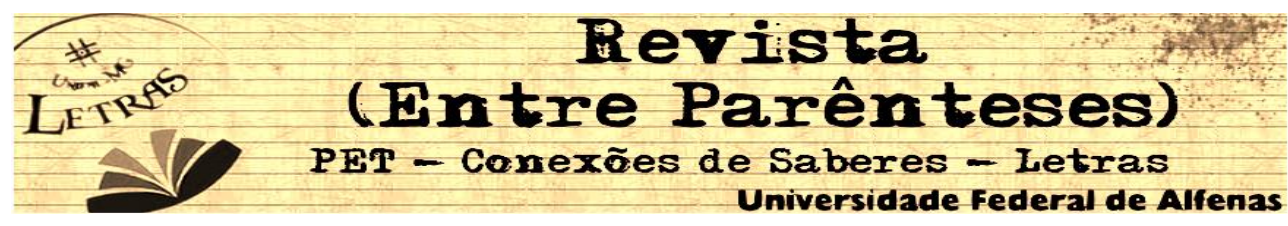

Isso acontece porque a ADF também considera outras dimensões da linguagem, como, por exemplo, onde o discurso é produzido, as questões históricas e sociais que se cristalizam no discurso, e o espaço próprio que cada discurso configura para si mesmo no interior de um interdiscurso. Podemos, nesse caso, observar a influência das obras de pesquisadores de outras áreas, como da Filosofia e da Sociologia. Isso faz despontar um caminho que exige uma ruptura das "caixinhas" das disciplinas e coloca o estudo do discurso num outro terreno no qual intervêm questões teóricas relativas à ideologia e ao sujeito.

Para a ADF, o discurso é uma prática, uma ação do sujeito sobre o mundo. Por isso, sua aparição deve ser contextualizada como um acontecimento, pois funda uma interpretação e constrói uma vontade de verdade. Assim, quando pronunciamos um discurso, agimos sobre o mundo, marcamos uma posição - ora selecionando sentidos, ora excluindo-os no processo da interlocução (CARNEIRO \& CARNEIRO, 2007).

A ADF recebeu diversos seguidores, o que ocasionou na criação de novas tendências, que denominaremos Análise do Discurso de Segunda Geração (usaremos a sigla AD neste trabalho). Nessa perspectiva, encontramos, dentre outras, a Semiolinguística, proposta por Patrick Charaudeau, que não despreza aquisições resultantes de pesquisas em Antropologia e em Sociologia, nem tampouco as aquisições da Pragmática. Diferentemente da ADF, que serviria, grosso modo, para desvendar a manipulação ideológica nos discursos e que consideraria o Homem como um ser políticopensante, a AD serviria para analisar os diferentes discursos e suas variantes, de uma cultura para outra, o que levaria a considerar a linguagem enquanto veículo social de comunicação e o Homem como um ser social 


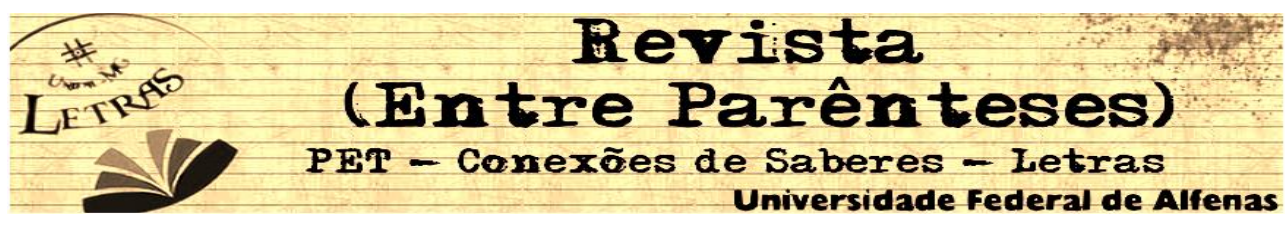

criado/condicionado pela sociedade/cultura do lugar onde vive.

Dessa forma, enquanto sujeito-falante, ele "repete" a voz do social, mas o lado psicossocial-situacional the garante também uma individualidade. Ou seja, ele não é nem completamente individual, nem completamente coletivo: é um amálgama dos dois, segundo Machado (2005).

Tendo em vista esta perspectiva, a AD nos proporciona alguns conceitos que vieram de outras áreas do conhecimento, como a Filosofia, Sociologia, Psicologia Social e Antropologia, que contribuem para um trabalho interdisciplinar. $\mathrm{Na}$ pesquisa que desenvolvo, há cinco conceitos muito importantes que passo a descrever para, posteriormente, ilustrar com um exemplo.

a) Ethos: o termo grego tem origem nos textos clássicos e designava a construção de uma imagem de si destinada a garantir o sucesso do empreendimento oratório, ou seja, são os traços de caráter que o orador deve mostrar ao auditório (pouco importando sua sinceridade) para causar boa impressão. No âmbito da AD, Ruth Amossy (2005) considera que todo ato de tomar a palavra implica a construção de uma imagem de si e o ethos seria a construção de uma representação de sua pessoa. Não é necessário que o locutor faça seu autorretrato ou detalhe suas qualidades, nem mesmo que fale explicitamente de si. Seu estilo, suas competências linguísticas e enciclopédicas, suas crenças implícitas são suficientes. Além disso, a apresentação de si não se limita a uma técnica apreendida, a um artifício. Ela, ao contrário, se efetua, frequentemente, à revelia dos parceiros, nas trocas verbais mais corriqueiras e mais pessoais. Como explica Charaudeau (2011, p. 118), o ethos é o resultado de uma Revista (Entre Parênteses) 


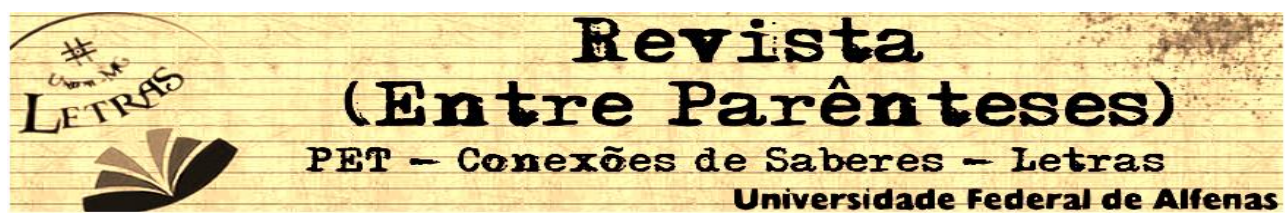

encenação social por meio da linguagem que "depende dos julgamentos cruzados que os indivíduos de um grupo social fazem uns dos outros ao agirem e falarem". Ou seja, as ideias são construídas por modos de dizer que passam por modos de ser, e o contrário também: os modos de ser comandam os modos de dizer as ideias.

b) Pathos: também de origem grega, o pathos seria o modo como se dispõe o ouvinte, levando-o a experimentar determinados efeitos emotivos. Dessa forma, enquanto o ethos pode ser relacionado à instância de produção do discurso, o pathos conduz nossa atenção para o auditório, isto é, para a instância (real ou imaginária) de recepção, incluindo aí suas suscetibilidades emocionais (GALINARI, 2007). As emoções aqui não devem ser entendidas como sensações fisiológicas, mas construções simbólicas sociais pois, como considera Le Breton (2009, p. 117), "o desencadeador das emoções é necessariamente um dado cultural tramado no âmago do vínculo social e nutrido por toda a história do sujeito. Ele mostra aos outros uma maneira pessoal de ver o mundo e de ser afetado por ele."

c) Imaginário: o termo foi amplamente usado pelo filósofo, economista e psicanalista francês Cornélius Castoriadis, e Patrick Charaudeau lança mão desse conceito incluindo o "sobrenome" sociodiscursivo. Assim, os imaginários sociodiscursivos são formados por um conjunto de julgamentos e conhecimentos que funcionam como uma espécie de mediação externa, o que permite aos indivíduos se reconhecerem como pertencentes a um grupo com o qual eles compartilham determinados imaginários. Tais imaginários consistem em um conjunto de representações que um grupo social ou um indivíduo constrói sobre o Revista (Entre Parênteses) 


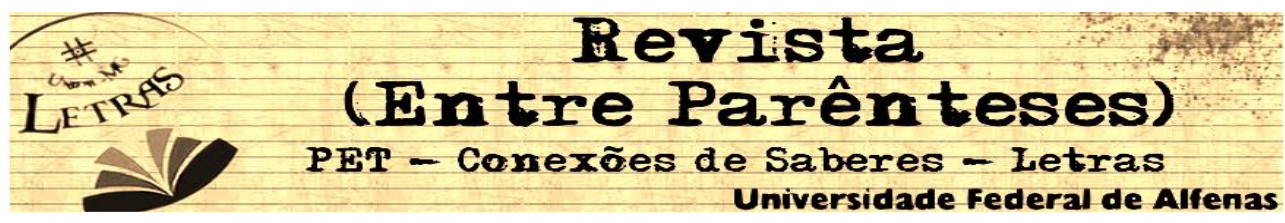

mundo. Estas representações testemunham as percepções do sujeito a respeito de tudo que o cerca e se relacionam aos valores atribuídos por ele. Além disso, os imaginários a que Charaudeau faz referência são sociais, isto quer dizer que são relativos aos conhecimentos, às crenças, aos valores que possuímos acerca de seres e objetos. Elas são formadas ao longo da vida e estão relacionadas com o local em que vivemos, com as pessoas com as quais convivemos, enfim, são externas.

d) Representação: esse termo é muito usado na Psicologia Social desenvolvida por Serge Moscovici. Charaudeau (2003) resume que as representações constroem uma organização do real mediante imagens mentais e estão incluídas na realidade, inclusive chegam a ser consideradas a própria realidade. Elas se apoiam na observação empírica da prática dos intercâmbios sociais e fabricam um discurso para justificá-los que cria um sistema de valores, erigido em norma de referência. Grosso modo, as representações dão testemunha de um desejo social, produzem normas e revelam sistemas de valores.

e) Sujeito: esse termo é utilizado em diversas áreas do saber humano. A AD usa-o de forma diferente da Gramática Normativa, por exemplo, que o classifica em simples, composto, indeterminado, oculto e inexiste. O sujeito do discurso não pode estar reduzido aos elementos gramaticais, pois ele é historicamente determinado. O sujeito é aquele que está inserido em uma sociedade e em tal foi criado, o que o leva a ter determinadas atitudes e a interpretar a dos outros sob determinados pontos de vista, apesar de constituir-se em ser único e com vivências diferentes caso se compare com outros sujeitos da mesma Revista (Entre Parênteses) 


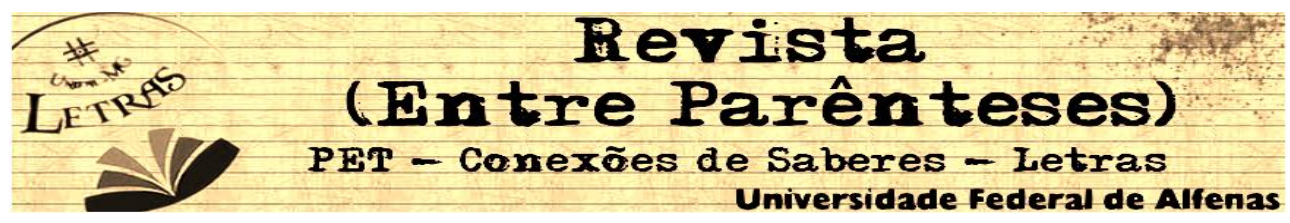

sociedade. Ele é histórico, social e descentrado. Descentrado porque é cindido pelas relações de poder e pelo inconsciente; histórico porque não está alienado do mundo que o cerca; e social porque não é o indivíduo, mas aquele apreendido num espaço coletivo. A constituição do sujeito discursivo é, pois, marcada por uma heterogeneidade decorrente de sua interação social em diferentes segmentos da sociedade. Isso implica três coisas: o sujeito não ocupa uma posição central na formação do discurso; ele não é necessariamente a fonte do que diz; muito menos tem uma identidade fixa e estável.

Tendo em vista esses termos e suas definições, minha pesquisa de doutoramento se centra em algumas perguntas básicas: Qual o imaginário atual que se tem dos homossexuais? De que forma a materialização discursiva da sexualidade e do gênero no corpo influencia a visão sobre o homossexual? De onde surgiu o padrão socialmente preestabelecido dos gêneros?

Como vimos, o gênero (e o sexo e a sexualidade) se constrói no e pelo discurso. Dessa forma, o sujeito genérico é inevitavelmente um sujeito discursivo e é na linguagem que ele existe. Respondendo a última pergunta que propus no parágrafo anterior, o padrão socialmente preestabelecido dos gêneros surgiu no discurso e recebeu "provas" ao longo da história da humanidade. Houve épocas, por exemplo, em que as mulheres eram vistas como homens invertidos, inclusive fisiologicamente. Essa "constatação" biológica da inferioridade da mulher era argumento suficiente para justificar elementos sociais, como sua proibição para votar, sua fraqueza emocional e moral etc.

No caso da homossexualidade não foi diferente (aliás, não é diferente). Ora o homossexual masculino era/é visto como um 


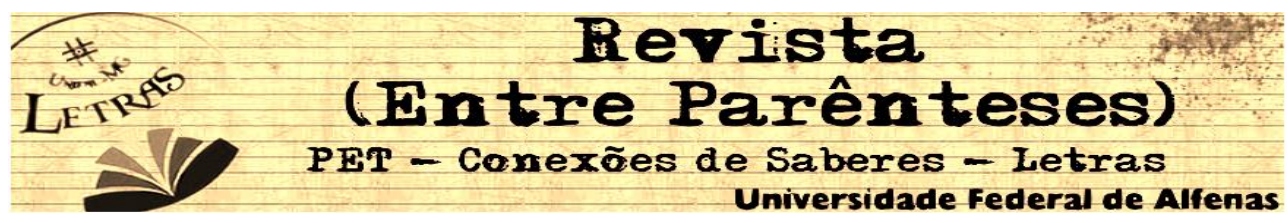

homem com alma de mulher, ora como uma mulher presa em um corpo masculino, ora como degenerado, ora como inevitavelmente pervertido. Ainda hoje, muitas religiões veem a homossexualidade como pecado contra a natureza. Todos esses são discursos compostos por representações que compõem imaginários sobre o(s) sujeito(s) homossexual(ais) e, na maioria das vezes, são negativos.

Observe este perfil do site de relacionamento gay Manhunt que coletei na época em que fazia minha monografia do final do curso de Bacharelado em Letras (2008):

'Tu te tornas eternamente responsável por aquilo que cativas!'

Um homem que vai para cama com outro não se torna nem precisa ser menos homem por isso. Sexo é diferente de sexualidade, sexo só existem dois (Masculino e Feminino), não existe um meio-termo entre eles, agora sexualidade é aquilo que sentimos, pelo menos penso assim, tentar ser ou parecer uma coisa que não somos e nunca seremos é uma demonstração podre de aceitação do ridículo.

Homem que se atrai por outro Homem:

*Não fala fino;

*Não conversa gritando;

*Não chama o outro de 'Bofe';

*Não chama mulher de 'Mona';

*Não usa saia nem batom

Perfil de wendawn (ALMEIDA, 2008)

O autor do perfil, cujo apelido usado é wendawn, inicia seu texto com uma citação do livro 'O Pequeno Príncipe'. No imaginário da nossa sociedade, esta obra literária está ligada à infância, ao afeto e, inclusive, ao concurso de Miss (é/era um lugar comum que as candidatas nesses concursos de beleza digam/dissessem que este é/era o seu livro de cabeceira). 


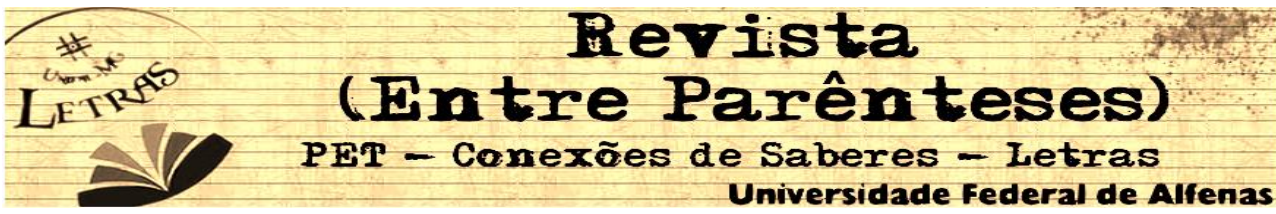

No entanto, a tentativa de atrair o público com um discurso patêmico (relativo a pathos, emoção) se vê resignificado com os argumentos seguintes. Wendawn descreve uma representação de homem e mulher, e também de masculino e feminino, baseada no senso comum de que existem apenas dois sexos: o masculino e o feminino. Entretanto, isso é uma convenção, já que esses dois termos não são relativos apenas aos órgãos genitais. O próprio autor do texto mostra que é mais que isso: o homem (masculino) não deve se comportar de forma diferente do que se espera de um ser que tem pênis, ou seja, não deve falar fino, nem conversar gritando, nem usar vocabulário específico (Bofe e Mona), nem fazer uso de objetos tipicamente femininos.

Nesse discurso, temos a manutenção do modelo de sexo bipolar, sem um "meio-termo". Essas características sociais estão definidas pelo falso fato de o sujeito possuir determinado órgão genital. $E$ isso não é opinião individual como Wendawn tenta modalizar dizendo "pelo menos penso assim". Essa voz social que ele reproduz é um caminho para o preconceito que, inclusive, ele já esboça em seu texto quando afirma que quando saímos desse padrão, na verdade tentamos "ser ou parecer uma coisa que não somos e nunca seremos" e isso "é uma demonstração podre de aceitação do ridículo".

Interessante observar a quantidade de frases negativas no perfil. A argumentação é quase toda baseada no que não é ou não deveria ser. A cada negação, inferimos uma afirmação e ainda podemos fazer ligações entre elas: 


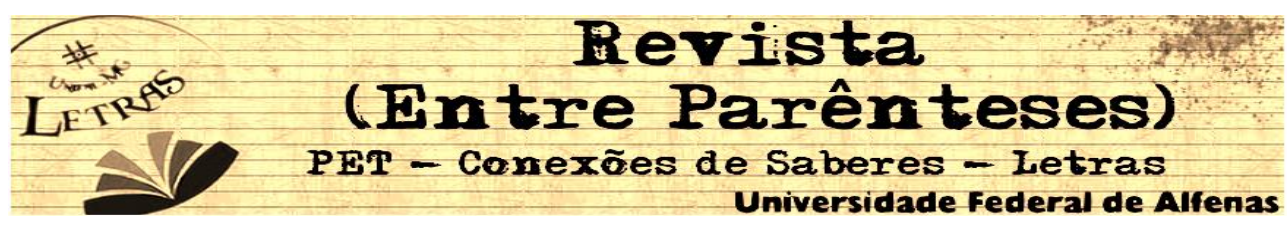

\begin{tabular}{|c|c|}
\hline Fragmento do perfil & Possíveis inferências \\
\hline $\begin{array}{l}\text { "Um homem que vai para cama } \\
\text { com outro não se torna nem } \\
\text { precisa ser menos homem por } \\
\text { isso" }\end{array}$ & homem gay também é homem \\
\hline $\begin{array}{l}\text { "Sexo é diferente de sexualidade, } \\
\text { sexo só existem dois (Masculino } \\
\text { e Feminino), não existe um meio- } \\
\text { termo entre eles" }\end{array}$ & homem gay é masculino \\
\hline $\begin{array}{l}\text { "tentar ser ou parecer uma coisa } \\
\text { que não somos e nunca seremos } \\
\text { é uma demonstração podre de } \\
\text { aceitação do ridículo." }\end{array}$ & $\begin{array}{l}\text { homem gay que tenta ser ou } \\
\text { parece feminino é uma } \\
\text { demonstração podre } \\
\text { aceitação do ridículo }\end{array}$ \\
\hline $\begin{array}{l}\text { Homem que se atrai por outro } \\
\text { Homem: } \\
\text { *Não fala fino; } \\
\text { *Não conversa gritando; } \\
\text { *Não chama o outro de 'Bofe'; } \\
\text { *Não chama mulher de 'Mona'; } \\
\text { *Não usa saia nem batom }\end{array}$ & $\begin{array}{l}\text { feminino pode falar fino, } \\
\text { conversar gritando, chamar um } \\
\text { homem de Bofe e uma mulher de } \\
\text { Mona, e pode usar saia e batom }\end{array}$ \\
\hline
\end{tabular}

Com esse quadro, parece claro o que o autor do perfil defende: "cada macaco no seu galho", ou melhor, seu discurso é tautológico: "homem é homem" e "mulher é mulher". Homem é sempre masculino, mesmo tendo relação sexual com outro homem. Ser masculino é não ser feminino. Ser feminino é usar batom, saia, falar fino etc. Com tantas negações, não temos um parâmetro do que é um homem gay, mas, sim, o que não deve ser. Negar, nesse caso, é uma estratégia que diz muito do que se quer evitar, do que é 


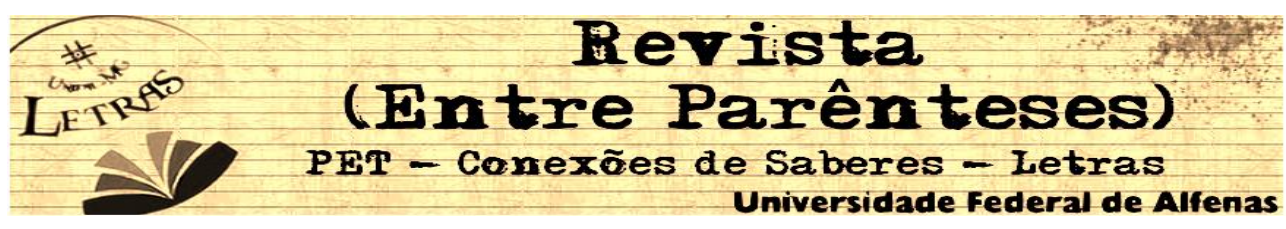

causa maior de desgosto, do que deve ser rechaçado e que é desvalorizado.

Outra observação que precisa ser feita é que, antes da lista de "recomendações" de um Homem de verdade (com H maiúsculo, diga-se de passagem), vemos a seguinte instrução: "Homem que se atrai por outro Homem". Temos aqui um exemplo de ato performativo maquiado de constatativo: parece que Wendawn descreve o homossexual ideal quando, na verdade, ele (re)cria e o mantém em seu discurso. Existe esse homossexual? Sim. Existe o outro? Sim, também. Na verdade, existem todos, porque todos nós, sujeitos classificados em homossexuais, heterossexuais, bissexuais, transexuais, travestis ou qualquer outra terminologia (ou a falta dela) somos vários e somos criados no e pelo discurso que é anterior a nós. Somos nomeados e classificados antes mesmo de nascer: "Olhe o ultrassom. É um menino!", "Ele se chamará Rafael", "Você é a cara do seu pai". Essa constatação, na verdade, tenta imprimir no sujeito determinado adjetivo e determinado comportamento. Isso pode ou não funcionar.

Daí surge a homossexualidade. Daí surge, aliás, a sexualidade, o sexo e o gênero do sujeito: não há padrão "natural", há padrões discursivos que se (re)constroem a todo momento, se repetem, são revisitados e são atuados no e pelo corpo.

\section{Considerações finais}

A relação entre a Teoria Queer e a $A D$ é muito importante para que se possa vislumbrar as representações que existem sobre os homossexuais em diversos discursos, tanto aqueles (re)produzidos pelos heterossexuais como pelos próprios 


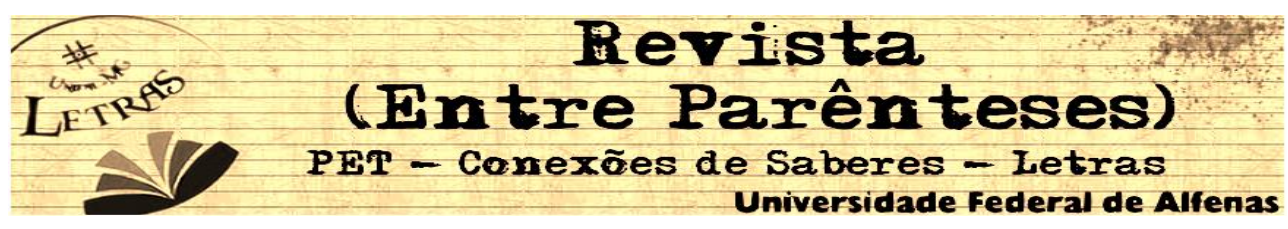

homossexuais. As perguntas poderiam ser, por exemplo, Que imaginários do gay são construídos em uma piada? Que representações sobre sexo, sexualidade e gênero são usadas em um artigo de opinião que defende/é contra o casamento entre homens ou entre mulheres? Que argumentos patêmicos são usados em um site de relacionamento para convencer o seu leitor de que o autor é um "bom partido" e em que imaginários se baseiam esses argumentos?

Desses questionamentos propostos podem nascer vários outros, o que vai variar dependendo do corpus formado para a pesquisa e da teoria a ser seguida. Aqui propus a Semiolinguística, mas ela não é a única dentro da Análise do Discurso. A pesquisa também é performativa: nunca é de essência, mas de atuação.

\section{Referências bibliográficas}

ALMEIDA, Daniel Mazzaro Vilar de. Gosto se discute? - análise de perfis de um site de relacionamento gay. Monografia (Bacharelado em Português) - Faculdade de Letras, UFMG, Belo Horizonte, 2008.

AMOSSY, Ruth. Da noção retórica de ethos à análise do discurso. In: AMOSSY, R. (Org.) Imagens de si no discurso. São Paulo: Editora Contexto, 2005. p. 9-28.

BRANDÃO, Helena $\mathrm{H}$. Nagamine. Introdução à análise do discurso. Campinas: Editora da UNICAMP, 2004.

BUTLER, Judith. Problemas de gênero: feminismo e subversão da identidade. Rio de Janeiro: Civilização Brasileira, 2010. 3. ed. 


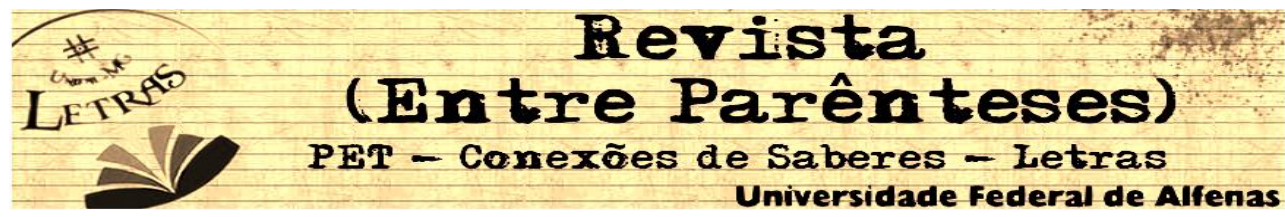

CARNEIRO, Eduardo de Araújo \& CARNEIRO, Egina Carli de Araújo Rodrigues. Notas introdutórias sobre a análise do discurso.

Parte 4: Fundamentos da Análise do Discurso. Disponível em: $<$ http://www.duplipensar.net/artigos/2007s1/notas-introdutoriasanalise-do-discurso-fundamentos.html>. Publicado em: 11 jul. 2007. Acesso em: 27 maio 2008.

CHARAUDEAU, Patrick. El discurso de la información: la construcción del espejo social. Barcelona: Gedisa Editorial, 2003.

CHARAUDEAU, Patrick. Discurso Político. São Paulo: Editora Contexto, 2011.

COSTA, Jurandir Freire. A face e o verso: estudos sobre o homoerotismo II. São Paulo: Editora Escuta, 1995.

FEMENÍAS, María Luisa. Judith Butler: Introducción a su lectura. Buenos Aires: Catálogos, 2003.

GALINARI, Melliandro M. As emoções no processo argumentativo. In.: MACHADO, I. L.; MENEZES, W.; MENDES, E. As emoções no discurso - v. 1. Rio de Janeiro: Lucerna, 2007, p. 221-239.

LE BRETON, David. As Paixões Ordinárias: Antropologia das emoções. Petrópolis, RJ: Vozes, 2009.

MACHADO, Ida Lucia. Algumas considerações sobre a Teoria Semiolinguística de Patrick Charaudeau. In: Movimentos de um percurso em Análise do Discurso. Belo Horizonte: FALE/UFMG, 2005. p. 19-32.

SALIH, Sara. Judith Butler e a Teoria Queer. Belo Horizonte: Autêntica Editora, 2012. 